\title{
The perspective of multi-religious society on Islamization policy in Malaysia
}

\begin{abstract}
Support for Islam has often been described as part of the Malaysian government's drive for Islamization, commonly known as 'Islamization policy'. The concept of an 'Islamization policy' is contested, open to various interpretations since it is not officially defined in any government blueprint. This paper highlights the perspectives of a number of religious groups on Islamization policy. The study covered the period from 1981 until 2009, which includes the Mahathir Mohamed and Abdullah Ahmad Badawi administrations. Using a policy analysis lens, the paper focuses on the perspective of the groups regarding the idea of Islamization as a public policy; the meaning and status of Islamization policy. The patterns indicate that the views are more complex than just 'for' and 'against,' although the patterns of perception are based on two divergent views: those who support the policy (the proponents) and those who oppose it (the opponents). This diversity is significant in that it helps to provide a better understanding of some multi-religious perspectives towards Islamization policy, as well as highlighting the different interests and concerns of both Muslim and nonMuslim communities towards the policy.
\end{abstract}

Keyword: Islamization; Islamization policy; Multi-religious society; Muslim and nonmuslim; Malaysia; Policy 